\title{
Response of Young and Maturing Citrus Trees Grown on a Sandy Soil to Irrigation Scheduling, Nitrogen Fertilizer Rate, and Nitrogen Application Method
}

\author{
Kelly T. Morgan ${ }^{1}$ \\ Soil and Water Science Department, University of Florida, Southwest \\ Florida REC, 2686 Sr 29 N, Immokalee, FL 34142
}

\section{T. Adair Wheaton, William S. Castle, and Laurence R. Parsons Horticultural Sciences Department, University of Florida, Citrus REC, 700 Experiment Station Road, Lake Alfred, FL 33850}

Additional index words. Citrus sinensis L., Entisols, Florida, nutrition, irrigation, controlledrelease fertilizer, fertigation, 'Ambersweet' orange

\begin{abstract}
This study examined the effect of irrigation rates, nitrogen (N) fertilizer rates, and methods of applying $N$ on growth and productivity of young ( 3 to 5 years old) and maturing (8 to 10 years old) citrus trees. A long-term study was conducted with the following objectives: 1 ) to measure the main effects of $\mathrm{N}$ rate, $\mathrm{N}$ application method, and irrigation on citrus tree growth and production from planting to maturity; 2) to establish growth and production relationships for long-term $\mathrm{N}$ rates and irrigation on welldrained sandy Entisols; and 3) to determine the effect of split fertilizer applications at two soil moisture regimes on citrus growth and production for two tree age classes as trees mature. Irrigation was applied using two selected ranges of soil moisture tensions and annual $\mathrm{N}$ rate varied by tree age as percentages of recommended. Methods of applying $\mathbf{N}$ included a dry granular fertilizer (DGF) containing soluble $\mathbf{N}$ applied four times annually or a controlled-release fertilizer (CRF) applied once per year and fertigation applied either four (FG04) or 30 (FG30) times annually. Canopy size and yield were higher with the moderate irrigation rate compared with the low rate for both young and maturing trees. Critical $\mathrm{N}$ rates for both canopy volume and yield were between 178 and $200 \mathrm{~kg} \cdot \mathrm{ha}^{-1}$. The CRF and FG30 treatments produced larger trees and higher yields compared with FG04 and DGF in the young tree study, indicating that younger trees benefitted from frequent split fertilizer applications. As the trees matured and filled their allocated space, the two irrigation rates were continued and $\mathrm{N}$ was applied at six rates using either DGF or FG30. For these 8- to 10-year-old trees, critical values of $\mathrm{N}$ application rates were 210 and $204 \mathrm{~kg} \cdot \mathrm{ha}^{-1}$ for DGF and FG30, respectively. The absence of a significant interaction between $\mathrm{N}$ rate and application method indicated that $\mathrm{N}$ uptake efficiency was similar for all application methods tested. DGF and FG30 treatments resulted in similar maturing tree yields and fruit total soluble solids. Canopy volumes, for the same trees, were significantly greater all 3 years with the FG30 treatment compared with DGF. Thus, if increase in tree size is desired, increased number of split applications will likely promote tree growth; however, little increase in fruit yield may be obtained.
\end{abstract}

Economic and environmental concerns require more precise management of irrigation and nutrition of citrus produced on the well-drained sandy Entisols of the central Florida ridge. Fertilizers are readily leached from these soils, and nitrate- $\mathrm{N}$ concentrations in groundwater above the allowed maximum contaminant limit have been attributed to application of nitrogen $(\mathrm{N})$ fertil-

\footnotetext{
Received for publication 20 Aug. 2008. Accepted for publication 25 Sept. 2008

We gratefully acknowledge the financial support of The City of Orlando and Orange County, without whom this research would not have been possible. ${ }^{1}$ To whom reprint requests should be addressed; e-mailktm@ifas.ufl.edu
}

applied between January and May during the period of flowering and maximum $\mathrm{N}$ demand (Obreza and Morgan, 2008). The current best management practice restricts application of $\mathrm{N}$ to citrus orchards on soils considered vulnerable to leaching of nutrients during the summer rainy period (FDACS, 2002; Obreza and Morgan, 2008). Maximum yields have been obtained with annual application of less than $225 \mathrm{~kg} \cdot \mathrm{ha}^{-1} \mathrm{~N}$ for citrus grown on the well-drained soils of the central Florida ridge (Alva et al., 2003; Davies, 1997). Syvertsen and Jifon (2001) found no effect of fertigation frequency (12 or 80 times per year) on tree growth and production or on the amount of fertilizer $\mathrm{N}$ taken up or leached. However, seemingly contradictory results have been found in studies examining the effect of application method to improve $\mathrm{N}$ use efficiency and reduce leaching on sandy Entisols. Schumann et al. (2003) found that the highest yields were obtained by fertigation (FG) with lower $\mathrm{N}$ application rates compared with DGF and controlled-release fertilizers (CRF). Leaf $\mathrm{N}$ values were higher per unit of applied $\mathrm{N}$ in the FG plots, indicating more efficient uptake. The authors concluded FG was the most efficient method of $\mathrm{N}$ application in this study, probably as a result of optimal placement and multiple applications. Likewise, Alva et al. (1998) found yield was slightly greater and loading of groundwater nitrate-N was lower using FG compared with DGF. Leaf nutrient concentration and fruit quality were unaffected by application method. In a separate study, Alva and Paramasivam (1998) found that yield and leaf $\mathrm{N}$ concentration increased with increasing $\mathrm{N}$ application rate. In that study, there was no significant interaction between $\mathrm{N}$ rate and application method, indicating that DGF, CRF, and FG were equally effective.

Fertilizer rate and method experiments on sandy Spodosols or Alfisols with confining layers at 1-m depth or less have had neutral or positive responses to application method (Obreza and Rouse, 1993; Rouse et al., 1999). The soil types in those studies were finer textured sandy soils with higher organic matter content, available water, and cation exchange capacities compared with the Entisols in the studies cited. Obreza and Rouse (1993) and Ferguson and Davies (1995) found that fertilizer source (CRF and DGF) had no effect on growth, yield, or fruit quality and the rate-by-source interaction was not significant. In a later study, Rouse et al. (1999) reported significantly increased yield of 3- to 5 year-old trees with CRF compared with DGF. However, there was no interaction of $\mathrm{N}$ rate and $\mathrm{N}$ source in this experiment. Reported yield of trees fertilized with DGF was similar to that of CRF when both were applied at a low rate. Similar yields among the two application methods would suggest similar uptake efficiency for both sources at the lowest rate. Greater yield with higher rates of CRF may suggest increased uptake efficiency compared with equal rates of DGF. 
Several field studies have determined the importance of proper irrigation scheduling on citrus growth and production on the low water and nutrient-retaining soils of central Florida (Boman, 1994; Morgan et al., 2006; Parsons et al., 2001; Scholberg et al., 2002). Field-scale fertilizer rate and method studies to date have been performed at a single irrigation schedule that varied from study to study. To determine the interaction of irrigation schedule, $\mathrm{N}$ application rate, and application method, a long-term study was conducted with the following objectives: 1) to measure the main effects and interactions of $\mathrm{N}$ rate, $\mathrm{N}$ application method, and irrigation on citrus tree growth and production from planting to maturity; 2) to establish growth and production relationships for long-term $\mathrm{N}$ rates and irrigation on welldrained sandy Entisols; and 3) to determine the effect of split fertilizer applications at two soil moisture regimes on citrus growth and production for two tree age classes as trees mature. To accomplish these goals, an experiment was conducted for a period of 10 years that provides additional information regarding the effects of irrigation and nutrient management on the growth and production of citrus trees on Entisols. Combining $\mathrm{N}$ rate and application method with irrigation schedule in a long-term experiment provided new insight into some of the contradictory results reviewed. Understanding the importance of irrigation rate, fertilizer $\mathrm{N}$ rate, and method of supplying $\mathrm{N}$ provides the basis for improved management of citrus and its environment on well-drained sandy soils.

\section{Materials and Methods}

'Ambersweet' orange trees [Citrus reticulata Blanco $\times(C$. paradisi Macf. $\times C$. reticulata $) \times$ midseason orange $C$. sinensis (L.) Osb.] on Swingle citrumelo rootstock [ $C$. paradisi Macf. $\times$ Poncirus trifoliata (L.) Raf.] grown in a commercial nursery were

Table 1. Factorial design ${ }^{\mathrm{z}}$ of irrigation scheduling and nitrogen $(\mathrm{N})$ fertilization treatments applied to young citrus trees (1993 to 1997) and maturing trees (1998 to 2002).

\begin{tabular}{|c|c|c|c|}
\hline Treatment & 1993-1994 & 1995-1997 & 1998-2002 \\
\hline \multicolumn{4}{|c|}{ Irrigation rate- - Soil water potential set points by month $(\mathrm{kPa})$} \\
\hline Low & \multicolumn{3}{|c|}{ February-May (10) June-January (15) } \\
\hline Moderate & \multicolumn{3}{|c|}{ February-May (8) June-January (12) } \\
\hline \multicolumn{4}{|c|}{ Annual $\mathrm{N}$ rate - Percentage of recommended annual $\mathrm{N}$ rate $\left(\mathrm{kg} \cdot \mathrm{ha}^{-1}\right)$} \\
\hline \multirow[t]{2}{*}{ Low } & $50(48)$ & $60(135)$ & $60(135)$ \\
\hline & - & - & $75(170)$ \\
\hline \multirow[t]{2}{*}{ Moderate } & $100(97)$ & $90(200)$ & $90(200)$ \\
\hline & - & - & $105(235)$ \\
\hline \multirow[t]{2}{*}{ High } & $200(195)$ & $120(270)$ & $120(270)$ \\
\hline & - & - & $135(300)$ \\
\hline \multicolumn{4}{|c|}{ Application method (applications per year) } \\
\hline Controlled release & 1 & 1 & - \\
\hline Dry soluble & 4 & 4 & 4 \\
\hline Low-frequency fertigation & 4 & 4 & - \\
\hline High-frequency fertigation & 30 & 30 & 30 \\
\hline
\end{tabular}

${ }^{\mathrm{z}}$ Experimental design was randomized complete block replicated four times. Each plot was treated with one irrigation rate, one annual $\mathrm{N}$ rate applied using one application method. The $\mathrm{N}$ rates and methods were changed over time to reflect increasing $\mathrm{N}$ rates with tree growth and the need to determine better resolution on interaction of the number of split applications and $\mathrm{N}$ rate on yield of maturing citrus trees. Data from the final 2 years of 1994 to 1997 and 1998 to 2002 were analyzed statistically with the beginning 2 years of each time period used as transition time from the previous treatments. potential values for the low irrigation rate were selected to increase intervals between irrigation events compared with soil water potentials of the moderate rate that would provide irrigation at current soil water depletion recommendations (Obreza and Morgan, 2008). Irrigation volume varied but averaged $300 \mathrm{~mm}$ annually for the low irrigation rated and $560 \mathrm{~mm}$ for the moderate rate. Each tree was irrigated by one microsprinkler emitter (Tornado; Plastro Irrigation Systems, Ltd., Ha'Amakim, Israel) with an output of 57 $\mathrm{L} \cdot \mathrm{hr} \mathrm{r}^{-1}$ distributed in a circular pattern $\approx 3.3 \mathrm{~m}$ in diameter. The reclaimed water met drinking water standards for most elements and contained a low concentration of $\mathrm{N}(\approx 7$ $\left.\mathrm{mg} \cdot \mathrm{kg}^{-1}\right)$. Previous work indicated the $\mathrm{N}$ at this concentration in reclaimed water did not contribute to the $\mathrm{N}$ requirements of citrus (Scholberg et al., 2002). Irrigation at the low and moderate rates with this water provided $\approx 11$ and $22 \mathrm{~kg} \cdot \mathrm{ha}^{-1} \mathrm{~N}$, respectively, for the two irrigation treatments.

\section{Fertilizer Rates and Application Methods}

Young tree study. Fertilizer rates were expressed on the basis of $\mathrm{N}$ rate because $\mathrm{N}$ is the primary limiting nutrient for citrus production in Florida (Mattos et al., 2003). The initial experiment included four equal split applications of DGF in February, March, May, and September and CRF applied once annually in February. These dry materials were applied by hand to a circle with a diameter of $\approx 0.5 \mathrm{~m}$ centered at the trunk of the young tree. The same rates of nutrient were also applied by fertigation either weekly from February to September [30 applications per year (FG30)] or four times per year at the same time the DGF was applied (FG04), but the area of application was much larger as a result of the distribution provided by the irrigation system. These placements of fertilizer are typical of commercial application methods. They result in concentration of the entire DGF and CRF nutrient loads over a relatively small area compared with FG30 or FG04 treatments. Beginning in 1995 (Year 3 ), all dry fertilizers were applied by a mechanical spreader in a band $\approx 2.5 \mathrm{~m}$ wide along the trunk row as is the common commercial practice for trees older than 3 years old.

The DGF and liquid FG formulations contained $8 \mathrm{~N}-0 \mathrm{P}-6.6 \mathrm{~K}$ with ammonium nitrate sources provided by local vendors. The CRF was a Meister ${ }^{\circledR}$ product (Helena Chemical Company, Fresno, CA) with a 9 -month release time. It contained $18 \mathrm{~N}-$ 2.6P-9.9K, and the $\mathrm{N}$ form was urea. Annual fertilizer $\mathrm{N}$ rates applied to individual trees in 1993 (Year 1) and 1994 (Year 2) were half, one, and two times recommended rates for Florida citrus (Koo, 1984) resulting in 0.09 , 0.18 , and $0.36 \mathrm{~kg} \mathrm{~N}$ per tree $(50,97$, and 195 $\left.\mathrm{kg} \cdot \mathrm{ha}^{-1}\right)$. At the time of this study, the recommended annual $\mathrm{N}$ rate changed from the rates stated previously to a flat $\mathrm{N}$ rate of $224 \mathrm{~kg} \cdot \mathrm{ha}^{-1}$ for both maturing and mature citrus trees (Tucker et al., 1995). Thus, 
fertilizer $\mathrm{N}$ rates were increased in Years 3 to 5 to $60 \%, 90 \%$, and $120 \%$ of the recommended $224 \mathrm{~kg} \cdot \mathrm{ha}^{-1}$ annual $\mathrm{N}$ rate (Table 1).

Maturing tree study. It was determined that little information existed about how N rate affected tree growth and early fruit yields as a young orchard developed; therefore, the main focus of the study from Years 6 to 10 was to determine the interaction of $\mathrm{N}$ application rate, irrigation scheduling, and number of split fertilizer applications on production. In the sixth year of this study, some treatments were modified to allow better resolution of the $\mathrm{N}$ rate effect. Irrigation treatments remained the same, but the number of $\mathrm{N}$ rates increased from three to six and application methods were reduced from four to two (Table 1). Treatments originally receiving FG30 or DGF applications were continued without modification. Plots receiving CRF or FG04 were maintained with the same irrigation treatments but were converted to the $\mathrm{N}$ rate closest to their previous value and to either DGF or FG30. Plots formerly receiving FG04 received DGF and plots that received $\mathrm{CRF}$ in the young tree study received FG30 in the mature tree study. Annual $\mathrm{N}$ rates were set at $60 \%, 75 \%, 90 \%, 105 \%, 120 \%$, and $135 \%$ of the recommended $224 \mathrm{~kg} \cdot \mathrm{ha}^{-1}$ (Table 1). For example, the CRF and FG04 treatments receiving $200 \mathrm{~kg} \cdot \mathrm{ha}^{-1}$ annually were converted to 170 or $235 \mathrm{~kg} \cdot \mathrm{ha}^{-1}$ annually applied as FG30 or DGF. These modified treatments were maintained for 2 years (Years 6 and 7) before data from the final 3 years (Years 8 to 10) of the experiment were collected. These changes provided six $\mathrm{N}$ rates and two methods of application along with the continuing two irrigation rates.

Data collection and sample analysis. Average canopy volume of the middle four trees was measured annually using a spheroid canopy shape model described by Whitney et al. (1991). To determine canopy volume, in-row and cross-row canopy diameters, tree height, and the highest point of canopy interception are used to estimate the volume of a truncated sphere. Fruit yield was measured by harvesting the middle 10 trees of each plot; the weight of fruit harvested from each plot was determined using commercial scales. Mean fruit diameter and fruit weights were measured for $\approx 20$ representative fruits per plot. Degrees Brix and total titratable acidity in the juice from the sample fruits were determined according to hygrometer and base titration methods approved for Florida citrus quality tests (Wardowski et al., 1995). Samples of spring growth leaves (20 leaves from 10 trees) were taken in June or August of each year. Leaf samples were analyzed for $\mathrm{N}$, phosphorus, and potassium. Leaf samples were dried at $70{ }^{\circ} \mathrm{C}$ to a constant weight and ground using a Cyclotec mill (Tecator Manufacturing, Tecator, Sweden). Ground tissue was analyzed for $\mathrm{N}$ by Kjeldahl methods (method 351.2; USEPA, 1993) using steam distillation (Buchi Analytical, Inc., New Castle, DE).

Statistical analysis. Treatments for both the young tree and maturing tree portions of the study were maintained for 5 years, but reported results are based on the last 3 years of each study. Data from the intervening 2 years were omitted as a transition from the young ( 3 to 5 years) to the maturing ( 8 to 10 years) trees. The general linear model procedure of SAS Version 9.1 (SAS, Inc., Cary, NC) was used to determine statistical significance of treatment main effects and interactions on canopy volume, yield, fruit size, juice content, juice quality, and leaf mineral content means. Generally, the effects of treatments were analyzed each year to allow yearly changes in the importance of individual factors in time to be more appar- ent. The critical point defined by a linear rise to plateau model was used to determine the minimum $\mathrm{N}$ rate for plots with significant $\mathrm{N}$ rate $\times \mathrm{N}$ application method interactions using the nonlinear regression procedure in SAS.

\section{Results and Discussion}

Young trees. Irrigation rate was not consistently linked with either $\mathrm{N}$ rate or $\mathrm{N}$ application method, but not in all 3 years. Irrigation rate $\times \mathrm{N}$ rate interactions were significant for yield in 2 of 3 years and total soluble solids (TSS) concentrations in all 3 years (Table 2). However, no significant effect of $\mathrm{N}$ rate or irrigation rate on fruit titratable acidity was found. Canopy size and yield of young trees generally increased as irrigation rate increased. Conversely, leaf $\mathrm{N}$ and TSS decreased with increased irrigation rate. Similar decreases in leaf $\mathrm{P}$ or potassium were not observed. The reduction in juice TSS was not a surprise, because dilution of juice from increased irrigation has been commonly observed (Koo and Smajstrla, 1984). However, TSS production per hectare was higher for the moderate irrigation rate as a result of the increased yield (data not shown). The $\mathrm{N}$ rate $\times$ application method interaction was significant for fruit yield in all 3 years and canopy volume in 2 of 3 years (Table 2). Method of nutrient application also influenced tree size and yield, but the effects changed with time. At the higher $\mathrm{N}$ rates, yield and tree size for the DGF method were considerably lower than for the other methods. Trees receiving the high rate of DGF were stunted and exhibited symptoms of high salt concentration in the root zone. Fertilizer salts can accumulate in the soil under Florida's dry spring conditions unless periodically leached (Syvertsen and Levy, 2005). The

Table 2. The effects of irrigation scheduling, nitrogen $(\mathrm{N})$ rate, and $\mathrm{N}$ application method on fruit yield, canopy volume, leaf $\mathrm{N}$ concentration, and juice quality of young citrus trees 3 to 5 years old.

\begin{tabular}{|c|c|c|c|c|c|c|c|c|c|c|c|c|}
\hline Treatment & \multicolumn{3}{|c|}{ Yield $\left(\mathrm{mg} \cdot \mathrm{ha}^{-1}\right)$} & \multicolumn{3}{|c|}{ Canopy volume $\left(\mathrm{m}^{3} /\right.$ tree $)$} & \multicolumn{3}{|c|}{ Leaf $\mathrm{N}\left(\mathrm{g} \cdot \mathrm{kg}^{-1}\right)$} & \multicolumn{3}{|c|}{$\begin{array}{l}\text { Juice total soluble } \\
\left.\text { solids ( }{ }^{\circ} \text { Brix }\right)\end{array}$} \\
\hline \multicolumn{13}{|l|}{ Irrigation } \\
\hline Moderate & 9.4 & 13.9 & 40.7 & 3.7 & 9.0 & 12.9 & 25.1 & 24.8 & 22.1 & 8.48 & 11.48 & 10.36 \\
\hline \multicolumn{13}{|l|}{$\mathrm{N}$ rate $\left(\mathrm{kg} \cdot \mathrm{ha}^{-1}\right)$} \\
\hline 135 & 3.7 & 12.7 & 29.7 & 3.4 & 7.3 & 10.8 & 24.9 & 24.2 & 21.8 & 8.65 & 11.46 & 10.30 \\
\hline \multicolumn{13}{|l|}{$\mathrm{N}$ method $^{\mathrm{z}}$} \\
\hline $\mathrm{CRF}$ & 6.5 & 16.9 & 39.6 & 3.5 & 7.8 & 11.3 & 25.5 & 25.8 & 22.7 & 8.89 & 11.78 & 10.57 \\
\hline DGF & 5.6 & 13.4 & 36.7 & 3.3 & 7.6 & 11.5 & 25.7 & 24.8 & 22.3 & 8.85 & 11.31 & 10.40 \\
\hline FG04 & 5.2 & 16.3 & 35.4 & 3.6 & 7.9 & 11.4 & 24.9 & 23.5 & 22.1 & 8.76 & 11.70 & 10.39 \\
\hline FG30 & 5.8 & 16.6 & 38.6 & 4.1 & 8.4 & 12.2 & 25.6 & 25.3 & 23.2 & 8.68 & 11.37 & 10.34 \\
\hline \multicolumn{13}{|c|}{ Statistics ${ }^{y}$} \\
\hline $\mathrm{N}$ rate by $\mathrm{N}$ method & $* *$ & * & * & ** & * & NS & NS & NS & NS & NS & NS & NS \\
\hline
\end{tabular}

${ }^{2}$ Fertilizer application methods; controlled-release (CRF), dry soluble (DSF), fertigation four times per year (FG04), and fertigation 30 times per year (FG30).

${ }^{\mathrm{y}}$ Statistical significances: NS $=$ nonsignificant; ${ }^{*},{ }^{*}=$ significant at $P<0.05$ and 0.01 , respectively. 
method of application for dry products (DGF and CRF) was changed in 1995 (Year 3) from hand application to a circle $\approx 0.5 \mathrm{~m}$ in diameter to a band $\approx 2.5 \mathrm{~m}$ wide as is typical of commercial practice. Changing the application method in Year 3 (1995) increased the surface area to which fertilizer was applied and reduced the effect of the high fertilizer application rate on a relatively small area. However, trees receiving DGF remained smaller compared with the other application methods until Year 5 (1997).

Reduced yield and tree size at the higher DGF rates suggests improved nutrient use efficiency of trees fertilized with CRF and FG30 or root injury as a result of salt burn from excessive fertilizer distributed to a small area. Accumulation of salts from fertilizer applications during dry spring seasons without adequate flushing of the root zone has been documented (Levy and Syvertsen, 2004; Syvertsen and Levy, 2005). The same annual $\mathrm{N}$ rate per tree was applied by all four methods. However, DGF and CRF were applied to a circle $\approx 0.5 \mathrm{~m}$ in diameter centered at the base of the tree. By contrast, the nutrients applied by the FG30 and FG04 methods were distributed with irrigation water to a circle $\approx 3.3 \mathrm{~m}$ in diameter. The application of the high rate of DGF immediately over the root zone resulted in injury and smaller tree size. The CRF was applied to the same small area as the DGF but did not cause injury as a result of its slow release characteristic. Note that the DGF applied at the lowest $\mathrm{N}$ rate was similar in size to FG30 and larger compared with the other two application methods (Fig. 1). Larger tree size with lower rates of DGF compared with the FG04 method may indicate that FG04 distributed

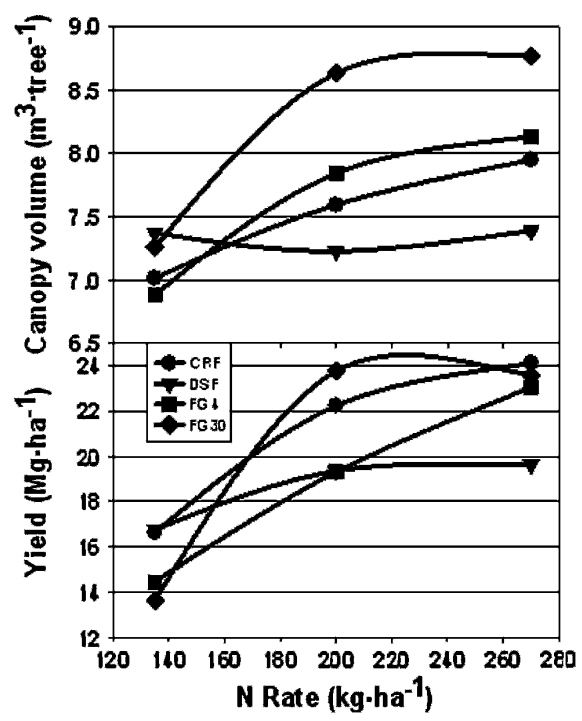

Fig. 1. Canopy volume and yield as a function of nitrogen $(\mathrm{N})$ rate by application method for the young trees (age, 3 to 5 years). The interaction of $\mathrm{N}$ rate with application method resulted from reduced canopy size and yield at higher rates of dry soluble fertigation. All values were similar at the lowest $\mathrm{N}$ rate indicating similar uptake efficiency among methods. fertilizer over an area larger than the existing root zone.

The largest trees at the higher $\mathrm{N}$ rates received the FG04 and FG30 treatments. Linear plateau analysis of the $\mathrm{N}$ rate by application method data indicates that the critical values or minimum $\mathrm{N}$ rates required to reach the canopy volume plateau were 182 , 198, and $199 \mathrm{~kg} \cdot \mathrm{ha}^{-1}$ for FG30, CRF, and FG04, respectively, representing canopy volumes of $8.4,7.6$, and $7.9 \mathrm{~m}^{3}$. The FG30 treatment produced larger trees with lower annual $\mathrm{N}$ rates compared with both $\mathrm{CRF}$ and FG4. Thus, the importance of application method to young trees was clearly demonstrated. The results also illustrate the problem of applying $\mathrm{N}$ as a fluid through an irrigation system that was designed for mature citrus trees, i.e., the wetting pattern extends beyond the root zone of younger trees. Applying optimum $\mathrm{N}$ rates before the root system expands to the entire irrigated area results in high potential loss of $\mathrm{N}$ and reduced $\mathrm{N}$ use efficiency.

The University of Florida-recommended $\mathrm{N}$ rates for young citrus trees at the time these applications were being made were excessive (Koo, 1984) and were reduced in subsequent recommendations (Tucker et al., 1995). The combination of an excessive recommended rate and DGF application by hand to a small area immediately over the small root zone of young trees probably resulted in root injury resulting from the salt content of the fertilizer, although this was not determined. The FG04 and DGF trees received the same amount of $\mathrm{N}$ per application, but the microsprinkler distributed the fertilizer to a larger area, much of which was beyond the root zone. Based on this interaction between $\mathrm{N}$ rate and method, recommendations for young tree fertilization have been reduced and the method of $\mathrm{N}$ application has been changed to avoid salt damage (Obreza and Morgan, 2008).

Leaf $\mathrm{N}$ and juice quality were also impacted by all three main factors (Table 2). Leaf $\mathrm{N}$ concentrations were generally within the recommended ranges for young trees, but they increased with increasing $\mathrm{N}$ rate and decreased with increased irrigation rate. Leaf nutrient status was significantly lower in FG04 plots compared with the other three methods.

With the exception of FG30, fruit yield of the young trees did not increase as $\mathrm{N}$ rate increased from 200 to $270 \mathrm{~kg} \cdot \mathrm{ha}^{-1}$ (Fig. 1). The linear plateau analysis indicates that the critical value for fruit yield was in the range of 177 to $188 \mathrm{~kg} \cdot \mathrm{ha}^{-1}$. Fruit yield for the FG30 method increased at the $270 \mathrm{~kg} \cdot \mathrm{ha}^{-1} \mathrm{~N}$ rate compared with the $200 \mathrm{~kg} \cdot \mathrm{ha}^{-1}$ rate, indicating that a plateau had not been reached for this application method.

Maturing trees. No consistent irrigation rate, $\mathrm{N}$ rate, or $\mathrm{N}$ application method interactions were found with the exception of a significant irrigation rate $\times \mathrm{N}$ rate interaction for TSS and $\mathrm{N}$ rate $\times \mathrm{N}$ application method interaction for canopy volume in 2 of 3 years (Table 3). Canopy size and yield were higher at the moderate irrigation rate compared with the low rate (Fig. 2). Like with the young tree study, TSS significantly decreased with increased irrigation, but TSS per hectare was greater with the higher irrigation rate (data not shown)

Equal yield, leaf N, and juice TSS were produced by the DGF and FG30 methods, but canopy volumes were significantly greater for FG30. Linear plateau analysis indicated that the critical $\mathrm{N}$ rates for yield were 210 and $204 \mathrm{~kg} \cdot \mathrm{ha}^{-1}$ for DGF and FG30, respectively. This result indicated little effect of greater number of fertilizer applications on yield (Fig. 2). The absence of significant $\mathrm{N}$ application rate interactions with application method for the maturing trees indicates that $\mathrm{N}$ uptake efficiency did not vary for split applications of $\mathrm{N}$. Instead, it suggests that citrus root systems are equally effective in capturing available $\mathrm{N}$ from frequent small fertilizer applications or from four much larger applications. Efficient uptake of $\mathrm{N}$ from very dilute soil solutions has been demonstrated (Scholberg et al., 2002). Syvertsen and Jifon (2001) found no benefit of frequent fertigation on tree growth, fruit yield, $\mathrm{N}$ uptake, or leaching losses in sandy soils. However, Quinous et al. (2003, 2005) found greater $\mathrm{N}$ use efficiency (NUE) with 66 split applications from a drip irrigation system compared with five applications with flood irrigation in a clay loam soil.

Effective uptake of $\mathrm{N}$ from more concentrated sources has also been observed. Mattos et al. (2003) estimated NUE for 6-year-old 'Valencia' trees grown in a sandy soil to be $40 \%$ and $26 \%$ for ammonium nitrate and urea, respectively. Feigenbaum et al. (1987) reported that the NUE for a ${ }^{15} \mathrm{~N}$-labeled $\mathrm{KNO}_{3}$ applied to 22-year-old 'Shamouti' orange was $40 \%$. Syvertsen and Smith (1996) estimated NUE to be $61 \%$ to $83 \%$ for 4 -yearold grapefruit trees grown in lysimeters. Nitrogen uptake efficiency decreased with increased $\mathrm{N}$ application rates. Lea-Cox and Syvertsen (1996) reported a similar finding of lower NUE with higher $\mathrm{N}$ application rate for greenhouse grown seedlings. The NUE reported ranged from $47 \%$ to $60 \%$ after an uptake period of $31 \mathrm{~d}$. Indirect evidence for efficient uptake of $\mathrm{N}$ from three to four annual applications comes from the common and successful commercial practice of providing the annual $\mathrm{N}$ requirement by this method.

It is not surprising that there was little effect of application method, assuming proper irrigation scheduling after application, because the methods have much in common. Ammonium nitrate is a common soluble source of $\mathrm{N}$ used in formulating DGFs and fluid fertilizers. Irrigation of DGF immediately after application is recommended to dissolve the ammonium nitrate and move it into the root zone to reduce losses resulting from ammonia volatilization. Irrigation immediately after DGF application thus differs little from applying fluid ammonium nitrate with irrigation water. Similarly, use of CRF may mimic multiple fertigations because both methods maintain low concentrations 
Table 3. The effects of irrigation scheduling, nitrogen $(\mathrm{N})$ rate, and $\mathrm{N}$ application method on fruit yield, canopy volume, leaf $\mathrm{N}$ concentration, and juice quality of maturing citrus trees 8 to 10 years old.

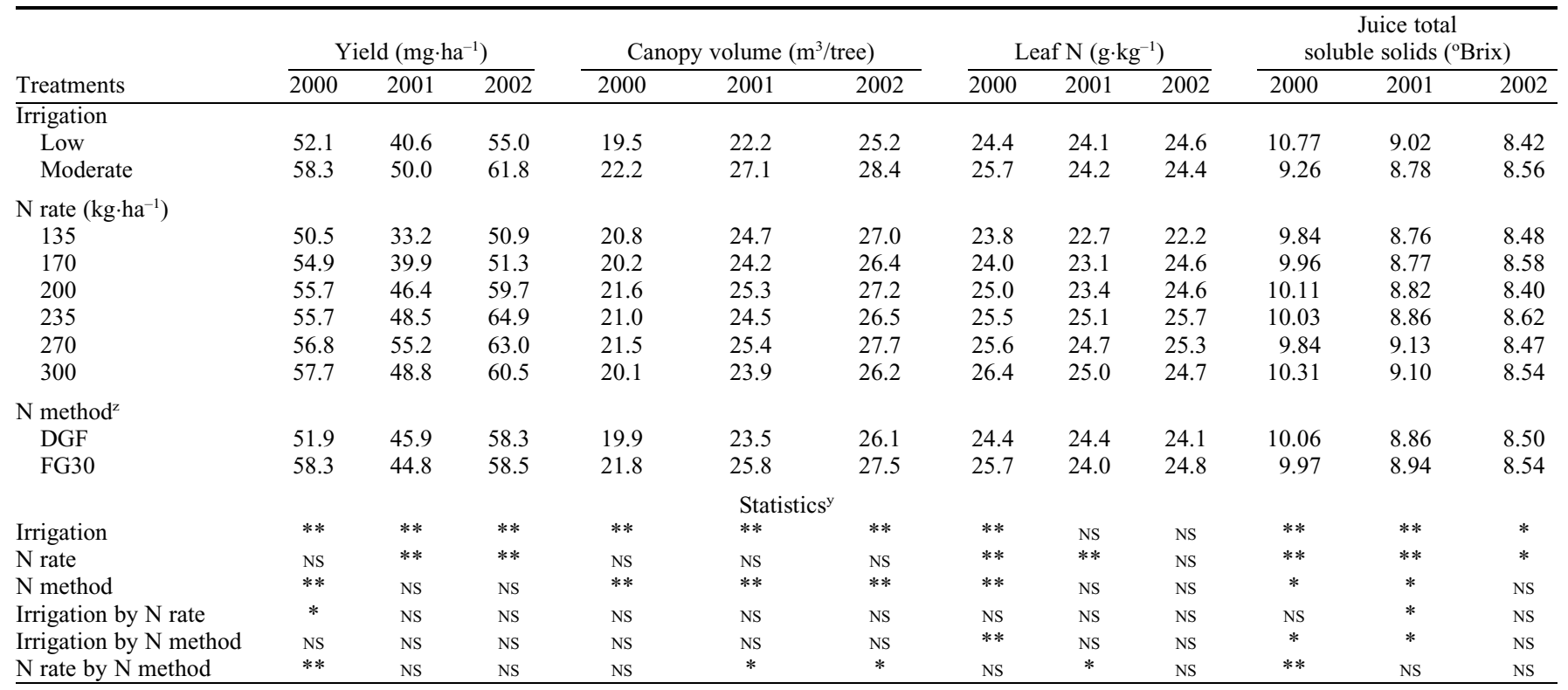

${ }^{2}$ Fertilizer application methods; dry soluble (DGF) and fertigation 30 times per year (FG30).

${ }^{\mathrm{y}}$ Statistical significances: NS $=$ nonsignificant; ${ }^{*}, * *=$ significant at $P<0.05$ and 0.01 , respectively.

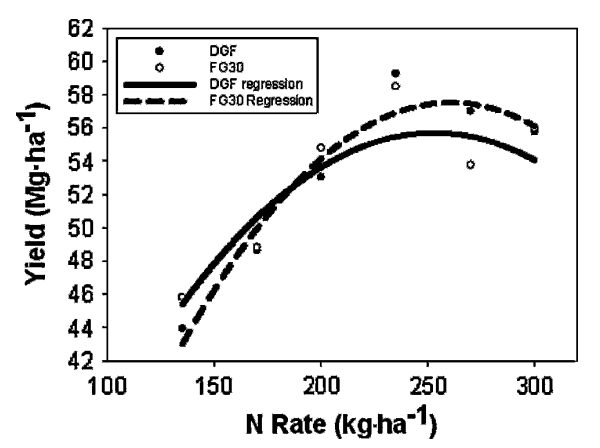

Fig. 2. Yield as a function of nitrogen $(\mathrm{N})$ rate by application method for maturing trees (age, 8 to 10 years). No consistent interaction between $\mathrm{N}$ rate and method indicates little effect of multiple applications on mature tree yields.

of $\mathrm{N}$ in the root zone for extended periods of time.

\section{Conclusions}

Canopy size and yield were higher with the moderate irrigation rate compared with the low rate for both young and maturing tree studies. Leaf $\mathrm{N}$ concentrations were within the optimum range for both irrigation rates indicating little adverse effect of increased irrigation amount on tree nutrient status with increased irrigation rate. The CRF and FG30 treatments produced larger trees and higher yields compared with FG04 and DGF in the young tree study, indicating that younger trees benefitted from frequent split fertilizer applications because it avoided potential root damage resulting from salt loading by DGF in relatively small application zones. However, DGF and FG30 treatments resulted in similar maturing tree yields and fruit TSS.
Canopy volumes, for the same trees, were significantly greater all 3 years with the FG30 treatment compared with DGF. These results support previous work showing little or no yield increase of splitting $\mathrm{N}$ into numerous small applications on the well-drained sandy soils of the central Florida ridge. However, tree size for maturing trees increases with increased split applications. Thus, if increase in tree size is desired, increased number of split applications will likely promote tree growth; however, little increase in fruit yield may be obtained. Optimum citrus production is possible from 8- to 10 -year-old trees with a maximum annual $\mathrm{N}$ rate of 200 to $235 \mathrm{~kg} \cdot \mathrm{ha}^{-1}$ or less.

It appears that the ability of citrus to store substantial quantities of $\mathrm{N}$ and to efficiently absorb it from both dilute and concentrated soil solutions makes application frequency unimportant in mature trees. The apparent salt damage from application of high rates to young trees, however, suggests that it is wise to avoid applying the entire annual $\mathrm{N}$ requirement to trees of small size using a soluble source applied infrequently over the relatively small root zone. The decline in yield frequently observed with fertilizer rates greater than $200 \mathrm{~kg} \cdot \mathrm{ha}^{-1}$ may be partially the result of excessive salt, particularly in areas where the salt content of irrigation water is a problem. One important aspect of more frequent applications of fertilizer is that less fertilizer nutrients are available for leaching if a rain event occurs after fertilizer application.

\section{Literature Cited}

Alva, A.K. and S. Paramasivam. 1998. Nitrogen management for high yield and quality of citrus in sandy soils. Soil Sci. Soc. Amer. J. 622:1335-1342.
Alva, A.K., S. Paramasivam, and W.D. Graham. 1998. Impact of nitrogen management practices on nutritional status and yield of Valencia orange trees and groundwater nitrate. J. Environ. Qual. 27:904-919.

Alva, A.K., S. Paramasivam, W.D. Graham, and T.A. Wheaton. 2003. Best nitrogen and irrigation management practices for citrus production in sandy soils. Water Air Soil Pollut. 143:140-154

Boman, B.J. 1994. A comparison of controlledrelease to conventional fertilizer on mature 'Marsh' grapefruit. Proc. Fla. State Hort. Soc. 106:1-4.

Davies, F.S. 1997. Nitrogen fertilization research on mature, bearing citrus trees-1880-1979. Citrus Industry Mag. 78:41-45.

FDACS. 2002. Nitrogen best management practices (BMPs) for Florida Ridge citrus. Fl. Dept. Agr. and Consumer Serv.

Feigenbaum, S., H. Bielorai, Y. Erner, and S. Dasberg. 1987. The fate of ${ }^{15} \mathrm{~N}$ labeled nitrogen applied to mature citrus trees. Plant Soil 97:179-187.

Ferguson, J.J. and F.S. Davies. 1995. Fertilization of young citrus trees with controlled release fertilizers. Proc. Fla. State Hort. Soc. 108:156160.

Koo, R.C.J. 1984. Recommended fertilizers and nutritional sprays for citrus. Univ. of Fla-IFAS, Bulletin 536D.

Koo, R.C.J. and A.G. Smajstrla. 1984. Effects of trickle irrigation and fertigation on fruit production and juice quality of 'Valencia' oranges. Proc. Fla. State Hort. Soc. 97:8-10.

Lea-Cox, J.D. and J.P. Syvertsen. 1996. How nitrogen supply affects growth and nitrogen uptake use-efficiency, and loss form citrus seedlings. J. Amer. Soc. Hort. Sci. 121:105114.

Levy, Y. and J.P. Syvertsen. 2004. Irrigation water quality and salinity effects in citrus trees. Hort. Rev. (Amer. Soc. Hort. Sci.) 30:37-82.

Mattos, D., D.A. Graetz, and A.K. Alva. 2003. Biomass distribution and nitrogen- 15 partitioning in citrus trees on a sandy Entisol. Soil Sci. Soc. Amer. J. 67:555-563. 
Morgan, K.T., T.A. Obreza, J.M.S. Scholberg, L.R. Parsons, and T.A. Wheaton. 2006. Citrus water uptake dynamics on a sandy Florida Entisol. Soil Sci. Soc. Amer. J. 70:90-97.

Obreza, T.A. and K.T. Morgan. 2008. Nutrition of Florida citrus trees. 2nd Ed. Univ. of FL-IFAS, Soil and Water Sci. Dept. Cir. SL253.

Obreza, T.A. and R.E. Rouse. 1993. Fertilizer effects on early growth and yield of 'Hamlin' orange trees. HortScience 28:111-114.

Parsons, L.R., T.A. Wheaton, and S.W. Castle. 2001. High application rates of reclaimed water benefit citrus tree growth and fruit production. HortScience 36:1273-1277.

Quinous, A., J. Banuis, E. Primo-Millo, and F. Lagaz. 2003. Effects of ${ }^{15} \mathrm{~N}$ application frequency on nitrogen uptake efficiency in citrus trees. J. Plant Physiol. 160:1429-1434.

Quinous, A., J. Banuis, E. Primo-Millo, and F. Lagaz. 2005. Recovery of the $15 \mathrm{~N}$ labeled fertiliser in citrus trees in relation with timing of application and irrigation. Plant Soil 268: 367-376.

Rouse, R.E., T.A. Obreza, and J.B. Sherrod. 1999. Yield and relative cost of controlled-release fertilizer on young bearing citrus trees. Proc. Fla. State Hort. Soc. 112:46-50.

Scholberg, J.M.S., L.R. Parsons, T.A. Wheaton, B.L. McNeal, and K.T. Morgan. 2002. Soil temperature, nitrogen concentration, and residence time affect nitrogen uptake efficiency in citrus. J. Environ. Qual. 31:759768.

Schumann, A.W., A. Fares, A.K. Alva, and S. Paramasivam. 2003. Response of 'Hamlin' oranges to fertilizer source, annual rate and irrigated area. Proc. Fla. State Hort. Soc. 116: 256-260.

Syvertsen, J.P. and J.L. Jifon. 2001. Frequent fertigation does not affect citrus tree growth, fruit yield, nitrogen uptake, and leaching losses. Proc. Fla. State Hort. Soc. 114:88-93.
Syvertsen, J.P. and Y. Levy. 2005. Salinity interactions with other abiotic and biotic stresses in citrus. HortTechnology 15:100-103.

Syvertsen, J.P. and M.L. Smith. 1996. Nitrogen uptake efficiency and leaching losses from lysimetergrown citrus trees fertilized at three nitrogen rates. J. Amer. Soc. Hort. Sci. 121:57-62.

Tucker, D.P.H., A.K. Alva, L.K. Jackson, and T.A Wheaton. 1995. Nutrition of Florida citrus trees. Univ. Fla. Coop. Extension Service, SPS 169.

USEPA. 1993. Determination of total Kjeldahl nitrogen by semi-auomated colorimetry-Method 352.1. U.S. Environ. Protection Agency.

Wardowski, W., J. Whigham, W. Grierson, and J. Soule. 1995. Quality tests for Florida citrus. Univ. of Fla., Bull. SP 99.

Whitney, J.D., A. Elezaby, W.S. Castle, T.A. Wheaton, and R.C. Littell. 1991. Citrus tree spacing effects on soil water use, root density, and fruit yield. Trans. ASAE 34:129-134. 